\title{
PENINGKATAN KUALITAS HIDUP PADA PENDERITA GAGAL GINJAL KRONIK YANG MENJALANI TERAPI HEMODIALISA MELALUI STRATEGI KOPING DI RSU ROYAL PRIMA MEDAN TAHUN 2019
}

\author{
${ }^{1}$ April Giawa, ${ }^{2}$ Chrismis Novalinda Ginting, ${ }^{3}$ Arniwati Tealumbanua, ${ }^{4}$ Ikhtiar Laia, ${ }^{5}$ Tedy Cristian \\ Manao \\ 1,2,3,4,5 Prodi S1-Keperawatan Fakultas Keperawatan Dan Kebidanan Universitas Prima Indonesia, Jl. \\ Belanga No. 1 simp. Ayahanda Medan \\ Email: ${ }^{1}$ aprilgiawa24@gmail.com, ${ }^{2}$ chrismis@unprimdn.ac.id, ${ }^{3}$ arniwatitit@gmail.com, \\ ${ }^{4}$ tiarlaia97@gmail.com, ${ }^{5}$ teddychristianmanao13@gmail.com
}

\begin{abstract}
ABSTRAK
Gagal Ginjal Kronik merupakan suatu keadaan klinis kerusakan ginjal yang progresif dan irreversible dari berbagai penyebab dimana terjadi ketika tidak mampu mengangkut sampah metabolik tubuh atau melakukan fungsi regulernya (Toto Suharyanto, 2017). Kualitas hidup merupakan salah satu yang dimiliki oleh setiap individu. Jika pasien menghadapi masalah dengan positif maka kualitas hidupnya akan baik, dan jika pasien menghadapi masalah dengan negatif maka kualitas hidupnya akan memburuk (Pujiani, 2017). Strategi coping terbagi dalam dua jenis yaitu : Emotion-Focused coping dan Problem Focused Coping.Emotion focused coping memiliki tujuan untuk mengontrol emosional pasien dalam menghadapi stress (Agustina, 2013). Tujuan penelitian ini bertujuan untuk mengetahui Peningkatan Kualitas Hidup pada Penderita Gagal Ginjal Kronik yang Menjalani Terapi HemodialisaMelalui Strategi Koping Di RSU Royal Prima Medan. Desain penelitian ini menggunakan desain pre-eksperimen dengan rancangan one group pre-test post-test design. Sampel diambil dengan menggunakan teknik accidental sampling yaitu sebanyak 30 orang. Pengumpulan data menggunakan lembaran kuisioner. Analisa data menggunakan uji Wilcoxon sign rank test dengan signifikasi 0,05. Hasil penelitian uji Wilcoxon sign rank test pada hasil akhir di dapatkan nilai $p=$ value 0,000 $<\alpha=0,05$ sehingga dapat diambil Kesimpulan bahwa adanya Peningkatan Kualitas Hidup Pada Penderita Gagal Ginjal Kronik Yang Menjalani Terapi Hemodialisa Melalui Strategi Koping Di RSU Royal Prima Medan. Saran untuk peneliti selanjutnya dapat meneliti bagaimana penigkatan kualitas hidup pada pasien stroke yang menjalani fisioterapi melalui strategi koping.
\end{abstract}

Kata Kunci : Kualitas Hidup, Strategi Koping.

\section{ABSTRACT}

Chronic kidney failure is a clinical state of progressive kidney damage and such of various causes which occur when metabolic waste transporting the incapacitated body or doing its regular functions (Toto Suharyanto, 2017). Quality of life is one that is owned by the individual, if the patient is facing problems with the quality of his life then positive will be good, and if patients face problems with negative then the quality of her life will deteriorate (Pujiani, 2017). Coping strategies are divided into two types, namely: Emotion-Focused coping and Problem Focused Coping. Emotion focused coping has the purpose to control the patient in the face of emotional stress (Agustina, 2013). The purpose of this research aims to know the KualitasHidup Improvement in people with Chronic renal failure undergoing Therapy In Koping Strategy Hemodialisa RSU Royal Prima Medan. This research design using design preexperimental design with one group pre test post test design. Samples were taken using the technique of accidental sampling that is as many as 30 people. Data collection using the questionnaire sheet. Analysis of test data using the Wilcoxon signed rank test with the significance of 0.05. Test research results Wilcoxon sign rank test on the final result in the get the value $p=0.000$ value $\alpha=0.05<$ so can be drawn the conclusion that an increase in the quality of life in people with Chronic renal failure Undergoing Therapy Through Hemodialisa Koping Strategy In RSU Royal Prima Medan. Suggestions for the next researcher can examine how penigkatan the quality of life in stroke patients who underwent physiotherapy through strategy koping.

KEYWORDS: Quality Of Life, Strategy Koping. 


\section{PENDAHULUAN}

Gagal Ginjal Kronik merupakan suatu keadaan klinis kerusakan ginjal yang progresif dan irreversible dari berbagai penyebab dimana terjadi ketika tidak mampu mengangkut sampah metabolik tubuh atau melakukan fungsi regulernya (Toto Suharyanto, 2017).

Gagal Ginjal Kronik saat ini semakin banyak menarik perhatian, karena pasien penyakit gagal ginjal kronik walaupun sudah mencapai tahap akhir, pasien harus dapat hidup dengan memiliki kualitas hidup yang cukup baik, pasien gagal ginjal kronik kualitas hidup mereka merupakan sesuatu yang tidak mudah untuk dicapai, bahkan pasien berpikir bahwa hidupnya tinggal hitungan hari dengan melampiaskan keputusannya yang tidak mengindahkan petunjuk dari tindakan tim medis (Desnauli dan Nursalam, 2011).

Kualitas hidup merupakan salah satu yang dimiliki oleh setiap individu, dimana setiap individu memiliki kualitas hidup yang berbeda tergantung dari kepribadian masing-masing individu dalam menyikapi suatu masalah yang terjadi dalam hidup pasien. Jika pasien menghadapi masalah dengan positif maka kualitas hidupnya akan baik, dan jika pasien menghadapi masalah dengan negatif maka kualitas hidupnya akan memburuk (Pujiani, 2017).

Pengobatan dan pencegahan gagal ginjal baik akut maupun kronis dapat mengendalikan gejala, meminimalkan komplikasi, dan menghambat perkembangan penyakit (As'adi Muhammad, 2012).

Hemodialisa atau cuci darah adalah suatu cara untuk memisahkan darah dari zat metabolisme dan racun dalam tubuh bila ginjal sudah tidak berfungsi lagi, hemodialisa di lakukan2-3 kali seminggu dengan lama waktu 4-5 jam. Proses hemodialisa sangat membantu pasien penderita penyakit gagal ginjal kronik sebagai upaya untuk memperpanjang usia penderita, meskipun proses ini membantu penderita mengembalikan fungsi ginjal yang sudah rusak, tetapi proses tersebut juga dapat menimbulkan masalah karena pasien berketergantungan pada mesin hemodialisa yang menyebabkan kualitas hidup pasien, psikologis, maupun sosial yang di rasakan penderita sebagai beban (Nurcahyati, 2016).

Pasien yang menjalani terapi cuci darah (Hemodialisa) dalam waktu yang cukup lama merasa depresi memikirkan sakit kronik dan takut terhadap kematian, penderita gagal ginjal kronik mengalami masalah lain yang berhubungan dengan kondisinya diantaranya masalah finansial, kesulitan dalam menghadapi pekerjaan serta hilangnya hasrat seksual dan akan mempengaruhi koping individu dan kualitas hidup mereka (Desnauli, 2012).

Strategi coping terbagi dalam dua jenis yaitu: Emotion-Focused coping dan Problem Focused Coping. Emotion focused coping memiliki tujuan untuk mengontrol emosional pasien dalam menghadapi stress. Yang termasuk dalam strategi coping Emotion-Focused Coping antara lain Selfcontrol yaitu usaha untuk mengontrol perasaan, Positive Reappraisal yaitu berusaha menciptakan makna baik dari suatu pengalaman yang berfokus pada perkembangan diri, Distancing, upaya melepaskan diri dari stress dan fokus pada pandangan yang positif.

Accepting Responsibility, melibatkan peran diri dalam suatu permasalahan. Escape-Avoidance, yaitu Perilaku untuk melarikan diri atau menghindar dari permasalahannya. Sedangkan Problem Focused Coping bertujuan mengurangi stress. Yang termasuk strategi coping dalam problem focused coping antaralain Confrontative coping yaitu usaha yang di lakukan untuk mengubah situasi, Seeking Social Support sebuah usaha mencari kenyamanan diri secara emosional serta mencari sumber informasi dari orang lain, Planful Problem Solving yaitu mendeskripsikan dan menghasilkan solusi untuk menyelesaikan stress (Agustina, 2013).

Strategi koping berfokus pada situasi stress reversible dan emosional. Stress yang reversible yaitu jika stressnya dapat di ubah atau di hilangkan. Sementara emosi berfokus mengatasi kasus-kasus stressor yang tidak berubah. Kedua Strategi koping ini saling berkaitan dalam mengatasi peristiwa stress (Silva, 2016).

Kualitas hidup di ukur dengan instrument World Health Organization Quality of Life (WHOQOL) yaitu kesehatan 
fisik, kesehatan psikologi, Tingkat independen, hubungan sosial lingkungan dan spiritual (WHOQOL, 2016).

Menurut WHO (World Health Organization) (2009) sampai tahun 2011 sebanyak 36 juta orang meningal dunia akibat penyakit ginjal kronik, di Amerika Serikat setiap tahun 50.000 orang meninggal akibat gagal ginjal, sedangkan yang di ketahui mendapatkan pengobatan hanya $25 \%$.

Menurut the United States Renal Data System (2011) menunjukkan prevalens rate penderita end stage renal disease tahun 2009 di Negara Amerika Serikat sebesar 1.811 per 1.000 .000 penduduk, di Negara Taiwan sebesar 2.447 per 1.000 .000 penduduk dan di Negara Jepang sebesar 2.205 per $1,000.000$ penduduk.

Berdasarkan hasil data Riskesdas (2018) menunjukkan bahwa prevalensi penyakit gagal ginjal kronik di Indonesia mengalami peningkatan dari 2,0\% pada tahun 2013 menjadi 3,8\% pada tahun 2018. provinsi dengan angka kejadian gagal ginjal kronik terbanyak adalah provinsi Kalimantan Utara $(6,4 \%)$ disusul oleh provinsi maluku utara $(6,1 \%)$, sedangkan provinsi dengan angka kejadian gagal ginjal kronik terendah adalah provinsi sulawesi barat $(1,7 \%)$, di Sumatra Utara sebanyak $(3,1 \%)$. hal ini menyebabkan bahwa gagal ginjal kronik memerlukan perhatian khusus (RISKESDAS, 2018).

Kartika, Agustina dan Triana Kesuma Dewi (2013) melakukan penelitian tentang strategi coping pada family caregiver pasien Gagal Ginjal Kronis yang menjalani hemodialisa dengan hasil penelitian menunjukan bahwa strategi coping sangat mempengaruhi pengontrolan diri terhadap masalah pada family caregiver, penelitian selanjutnya yang dilakukan oleh Wutun, Engelbertus dkk (2016) mengenai gambaran mekanisme koping pada pasien gagal ginjal kronik yang menjalani terapi hemodialisa di ruang hemodialisa. Hasil dari penelitian yang sudah dilakukan terhadap 57 orang dimana, sebanyak 52 orang $(91 \%)$ menggunakan koping adaptif dan 5 orang (9\%) koping maladaptif menunjukan bahwa pentingnya dilakukan mekanisme koping pada pasien gagal ginjal kronik yang menjalani hemodialisa.
Berdasarkan hasil peneliti pada survei awal bulan Desember terakhir tahun 2018 terdapat pasien Gagal Ginjal Kronik di RS Royal Prima Medan ruang Hemodialisa sebanyak 796 orang, pada tanggal 10 April 2019 terhitung dalam bulan Maret terdapat 120 orang pasien gagal ginjal kronik yang sedang menjalani terapi Hemodialisa. Dalam kurun waktu satu minggu pasien mendapat terapi hemodialisa 2 sampai 3 kali dalam waktu 5 jam sehari. Berdasarkan hasil wawancara peneliti terhadap beberapa pasien yang sedang menjalani terapi hemodialisa didapat bahwa pasien mememiliki kualitas hidup yang rendah, kurangnya dukungan keluarga, menurunnya kepatuhan pasien dalam menjalani terapi hemodialisa, serta pasien terlihat mengalami stress dan cenderung menutup diri dalam mengahadapi penyakitnya. Beberapa pasien yang menjalani terapi hemodialisa memiliki kualitas hidup yang baik terlihat dari motivasi diri pasien yang sangat tinggi dalam menjalani terapi hemodialisa dan mengikuti jadwal terapi yang telah ditentukan serta memiliki keluarga yang berperan aktif dalam mendukung pasien dalam menjalani terapi.

\section{METODE}

Jenis penelitian ini merupakan penelitian pre-experiment maka penelitian ini menggunakan rancangan one group pre dan post test design. Tempat penelitian ini dilakukan di Ruang Hemodialisa di RSU Royal Prima Medan dengan alasan karena di RSU Royal Prima terdapat pasien gagal ginjal kronik dimana nantinya akan dijadikan sebagai sampel penelitian dan RSU Royal Prima Medan memiliki angka penyakit gagal ginjal kronik yang mengalami peningkatan yang signifikan. Populasi penelitian ini terhitungbulan Maret 2019 sebanyak 120 orang.

Sampel adalah 30 orang sebagian atau wakil populasi yang di teliti (Arikunto, 2006). Pengambilan sampel pada penelitian ini dilakukan dengan teknikaccidental sampling. Teknik pengumpulan data yang dilakukan dalam penelitian ini adalah data primer di peroleh dari responden langsung dengan mengajukan 26 pertanyaan untuk kuesioner kualitas hidup, dan 20 pertanyaan untuk strategi koping. Sedangkan data 
sekunder diperoleh dari data rekam medik pasien.

Analisa data dilakukan dengan menggunakan uji wilcoxon pada tingkat kepercayaan 95\% $(\mathrm{p}<0,05)$. dimana nilai signifikannya apakah $\mathrm{Ha}$ diterima jika $\mathrm{p}<$ 0,05 maka, terdapat peningkatan kualitas hidup pada pasien gagal ginjal kronik yang menjalani terapi hemodialisa melalui strategi koping. Apakah Ho ditolak Jika p >0,05 maka, tidak terdapat peningkatan kualitas hidup pada pasien gagal ginjal kronik yang menjalani terapi hemodialisa melalui strategi koping.

\section{HASIL}

\section{Univariat}

Tabel 1. Distribusi Karakteristik Berdasarkan Jenis Kelamin dan Umur Responden Pada Penderita Gagal Ginjal Kronik Yang Menjalani Terapi Hemodialisa di RSU Royal Prima Medan

\begin{tabular}{ccc}
\hline $\begin{array}{c}\text { Distribusi } \\
\text { Karakteristik }\end{array}$ & $\begin{array}{c}\text { Jumlah } \\
(\mathbf{n})\end{array}$ & $\begin{array}{c}\text { Persentase } \\
(\boldsymbol{\%})\end{array}$ \\
\hline Jenis kelamin & & \\
\hline Laki- Laki & 18 & 60 \\
\hline Perempuan & 12 & 40 \\
\hline Total & 30 & 100 \\
\hline
\end{tabular}

\begin{tabular}{ccc}
\hline Umur & & \\
\hline $30-40$ Tahun & 6 & 20 \\
\hline 41-50 Tahun & 10 & 33,3 \\
\hline 51-60 Tahun & 11 & 36,7 \\
\hline 61-70 Tahun & 3 & 10 \\
\hline Total & 30 & 100 \\
\hline
\end{tabular}

\section{Analisi Bivariat}

Tabel 2. Distribusi Kualitas Hidup Pasien Gagal Ginjal Kronik Sebelum (pre-test) Menjalani Strategi Koping di Unit Hemodialisa di RSU Royal Prima Medan

\begin{tabular}{ccc}
\hline Variabel & Jumlah (n) & Persentase (\%) \\
\hline Kualitas Hidup & & \\
\hline Baik & 0 & 0 \\
\hline Cukup & 17 & 56,7 \\
\hline Kurang & 13 & 43,3 \\
\hline Total & 30 & 100 \\
\hline
\end{tabular}

Tabel 3. Distribusi Kualitas Hidup Pasien Gagal Ginjal Kronik Sesudah (post-test) Menjalani Strategi Koping di Unit Hemodialisa di RSU Royal Prima Medan

\begin{tabular}{ccc}
\hline Variabel & Jumlah (n) & Persentase (\%) \\
\hline Kualitas Hidup & & \\
\hline Baik & 8 & 26,7 \\
\hline Cukup & 17 & 56,7 \\
\hline Kurang & 5 & 16,7 \\
\hline Total & 30 & 100 \\
\hline
\end{tabular}

Tabel 4. Pengaruh Strategi Koping Pasien Gagal Ginjal Kronik Terhadap Kualitas Hidup di Unit Hemodialisa di RSU Royal Prima Medan

\begin{tabular}{cccccc}
\hline $\begin{array}{l}\text { Variabel } \\
\text { Kualitas Hidup }\end{array}$ & Mean Rank & $\begin{array}{l}\text { Variabel Strategi } \\
\text { Koping }\end{array}$ & Jumlah (n) & $\begin{array}{c}\text { Persentase } \\
(\boldsymbol{\%})\end{array}$ & P-Value \\
\hline Pre - Test & 7,50 & Baik & 8 & 26,7 & \\
\hline & & Cukup & 16 & 53,3 & 0,000 \\
\hline Post - Test & 0,000 & Kurang & 6 & 20 & \\
\hline & & Total & 30 & 100 & \\
\hline
\end{tabular}

\section{PEMBAHASAN}

Pembahasan ini menjelaskan hasil penelitian mengenai peningkatan kualitas hidup pada penderita gagal ginjal kronik yang menjalani terapi hemodialisa melalui strategi koping di RSU Royal Prima Medan. Pada data karakteristik terdapat mayoritas responden berjenis kelamin Laki-laki dan minoritas perempuan hal ini tidak memiliki pengaruh penigkatan kualitas hidup Dan mayoritas rentang umur responden 51-60 Tahun dan minoritas 61-70 Tahun Hal ini juga tidak memiliki pengaruh terhadap kualitas hidup responden.

Dari data diatas terdapat distribusi Kualitas Hidup responden Sebelum (pretest) melalui Strategi Koping dengan mayoritas responden memiliki kualitas hidup cukup dan Minoritas responden memiliki kualitas hidup baik. Menurut peneliti hal ini menunjukan bahwa kualitas hidup pasien sebelum melalui strategi koping masih tergolong cukup dan kurang karena rata-rata responden belum memahami bagaimana melakukan strategi 
koping yang baik untuk menigkatkan kualitas hidup, hal ini ditunjukan dengan tidak adanya responden yang memiliki kualitas hidup baik.

Hal ini sejalan dengan penelitian yang dilakukan oleh Hutagaol (2017), yang berjudul peningkatan kualitas hidup pada penderita gagal ginjal kronik yang menjalani terapi hemodialisa melalui psychological intervention diunit Hemodialisa RS Royal Prima Medan Tahun 2016. Dimana pada penelitian tersebut mayorital responden memiliki kualitas hidup kurang dan Cukup.

Dari data diatas terdapat distribusi strategi koping responden sesudah (posttest) melalui Strategi Koping dengan mayoritas responden memiliki Strategi koping cukup dan Minoritas responden memiliki Strategi koping kurang. Menurut peneliti hal ini menunjukan bahwa ada peningkatan kualitas hidup setelah melalui strategi koping dengan adanya responden yang memiliki kualitas hidup yang baik walaupun tidak mayoritas. rata-rata responden masih memiliki kualitas hidup cukup namun penigkatan kualitas hidup yang baik menigkat setelah diberikan strategi koping ini menunjukan keberhasilan melakukan strategi koping dapat menigkatkan kualitas hidup responden dengan melakukan strategi koping responden dapat menyelesaikan masalah yang dihadapi dan menyesuaikan diri

Hal sama dengan penelitian Hutagaol (2017), yang berjudul peningkatan kualitas hidup pada penderita gagal ginjal kronik yang menjalani terapi hemodialisa melalui psychological intervention diunit Hemodialisa RS Royal Prima Medan Tahun 2016 dimana pada penelitian tersebut terjadi peningkatan kualitas hidup baik dengan persentase, cukup dan kualitas kurang.

Hasil uji wilcoxon memiliki nilai $<0,05$ hal ini menunjukan bahwa ada peningkatan kualitas hidup pada penderita gagal ginjal kronik yang menjalani terapi hemodialisa melalui strategi koping di RSU Royal Prima Medan. hal ini sama dengan penelitian yang di lakukan Hutagaol (2017), yang berjudul peningkatan kualitas hidup pada penderita gagal ginjal kronik yang menjalani terapi hemodialisa melalui psychological intervention diunit Hemodialisa RS Royal Prima Medan Tahun 2016 dimana pada penelitian tersebut terjadi peningkatan kualitas hidup Responden.

Dari data diatas terdapat gambaran distribusi strategi koping responden berdasarkan focused coping dengan mayoritas responden memiliki Strategi koping cukup dan kemudain Baik \& Minoritas responden memiliki Strategi koping kurang. dan berdasarkan emotion koping mayoritas responden memiliki strategi koping cukup dan minoritas strategi koping baik.

Menurut peneliti strategi koping dapat menigkatkan kualitas hidup karena responden dapat mengontrol dan menyelesaikan masalah yang dihadapi baik dengan melalui strategi focused coping (mencari penyelesain masalah yang dihadapi) dengan cara menghindari permasalahan dengan selalu berpikir positif, berhati-hati, teliti, mengembangkan diri dengan berdoa, dan tidak tergesah-gesah dalam mengambil tindakan maupun dengan emotion coping (menyesuaikan diri dan melibatkan usaha) dengan cara mencari dukungan dari keluarga, sahabat, dll.

Berdasarkan penelitian yang telah dilaksanakan dapat diketahui bahwa mayoritas responden yang menggunakan strategi focused mengalami penigkatan kualitas hidup yang baik. sehingga dapat di simpulkan bahwa strategi koping yang berpengaruh adalah strategi focused coping. hal ini sejalan dengan penelitian Desnauli, Nursalam, Efendi, (2011) yang berjudul indikator kualitas hidup pasien gagal ginjal kronis yang menjalani hemodialisa berdasarkan strategi koping yang mengatakan bahwa strategi koping dapat memperbaiki kualitas hidup pasien gagal ginjal kronis yang menjalani hemodialisa. Setelah melalui strategi koping terjadi peningkatan kualitas hidup pada penderita gagal ginjal kronik yang menjalani terapi hemodialisa melalui di RSU Royal Prima Medan sehingga dapat diterapkan kepada penderita gagal ginjal kronik yang menjalani terapi hemodialisa.

\section{KESIMPULAN}

Berdasarkan hasil penelitian yang kami lakukan mengenai Peningkatan Kualitas Hidup Pada Penderita Gagal Ginjal Kronik Yang Menjalani Terapi Hemodialisa Melalui 
Strategi Koping Di RSU Royal Prima Medan Tahun 2019 maka didapat kesimpulan bahwa :

Distribusi karakteristik responden berdasarkan umur dengan mayoritas responden berumur 51-60 Tahun dengan persentase $36 \%$ (11 responden) dan minoritas responden berumur 61-70 Tahun dengan persentase $10 \%(3$ responden). Distribusi karakteristik responden berdasarkan jenis kelamin dengan mayoritas responden berjenis Kelamin Laki-Laki dengan persentase 60\% (18 responden) dan minoritas responden berjenis kelamin Perempuan.

Kualitas hidup pada responden berdasarkan pengukuran sebelum (pre-test) melalui strategi koping dengan mayoritas responden pada kategori cukup dan minoritas baik. Hasil pengukuran setelah (post-test) melalui strategi koping kualitas hidup responden dengan mayoritas responden pada kategori cukup dan minoritas kurang.

Ada pengaruh peningkatan jumlah kualitas hidup responden dari nilai kualitas hidup yang kurang menjadi baik pada penderita gagal ginjal kronik yang menjalani

Gagal Ginjal Kronis Yang Menjalani Hemodialisa. Jurnal Psikologi Klinis Dan Kesehatan Mental. Diakses pada tanggal 29 Mei 2017. URL: http://journal.unair.ac.id/downloadfullpapers-jpkkac9d7cddc8full.pdf.

Efendi, F. Nursalam \& Evi Desnauli. (2011). Indikator Kualitas Hidup Pasien Gagal Ginjal Kronis Yang Menjalani Hemodialisa Berdasarkan Strategi Koping. Jurnal Ners 6(2), 187-191. Diakses pada tanggal 8 Juli 2018. URL: https://ejournal.unair.ac.id/JNERS/article/view/ 3990..

Golafshani, H. Z.S. Dkk. (2019). Hubungn Antara Stress Dan Coping Strategi diIran Pasien menjalani Hemodialisa. Diakses pada tanggal 8 Februari 2007. $U R L$ :

https://www.ncbi.nlm.nih.gov/pubmed/1 7289821.

Hutagaol, E. V. (2017). Peningkatan Kualitas Hidup Pada Penderita Gagal Ginjal Kronik Yang Menjalani Terapi Hemodialisa Melalui Psychological terapi hemodialisa melalui strategi koping di RSU Royal Prima Medan Tahun 2019.

\section{SARAN}

Untuk tenaga medis dan para medis untuk selalu memberikan sosialisa bagaimana melakukan strategi koping pada pasien gagal ginjal kronis menjalani hemodialisa sehingga kualitas hidup pasien dapat meningkat, untuk pasien gagal ginjal kronis yang menjalani hemodialisa untuk selalu menjaga koping dengan melakukan berbagai strategi koping tersebut, Hendaknya untuk penelitian selanjutnya supaya meneliti bagaimana penigkatan kualitas hidup pada pasien stroke yang menjalani fisioterapi melalui strategi koping.

\section{DAFTAR PUSTAKA}

Astuti, Anggorowati \& Kusuma. (2017). Self Managemen Terhadap Psychosocial Atjusmen Pasien Penyakit Ginjal Kronik Dengan Hemodialisa. Jurnal Keperawatan Soediman. 12(3), 1907-6673.

Dewi, K. T. \& Kartika A. (2013). Stratgi Coping Pada Family Caregiver Pasien Intervention di Unit Hemodialisa RSU Royal Prima Medan Tahun 2016. Jurnal Jumantik 2(1) 2548-2173.

Karim, D \& Nurcahayati, S. (2016). Implementasi Self Care Model Dalam Upaya Meningkatkan Kualitas Hidup Penderita Gagal Ginjal Kronik. Jurnal Keperawatan Sriwijaya. 3(2), 23555459. Diakses pada tanggal 20 september $2016 . \quad$ URL: https://www.neliti.com/id/publications/ 181763/implementasi-self-care-modeldalam-upaya-meningkatkan-kualitashidup-penderita-g.

Maryam, Siti. (2017) Strategi Coping: Teori Dan Sumber dayanya. Jurnal konseling andi matappa 1(2), 2549-1857. Diakses pada tanggal 25 Maret 2019. URL: https://www.researchgate.net/publicati on/324997235 Strategi Coping Teori Dan_Sumberdayanya.

Masruroh \& Pujiani. (2017). Program Psikoedukasi Terhadap Peningkatan Kualitas Hidup Pasien Gagal Ginjal Kronik. Jurnal EDUNursing. 1 (1), 2549-8207. Diakses pada tanggal 21 
januari 2017. http://journal.unipdu.ac.id:8080/index. php/edunursing/article/view/759.

Silva, Da R. A. R. (2016). Coping Strategies Used By Kidney Failure Patients For Chronic Hemodialis Treatment Strategies Used For Patients With Chronic Renal Failure In Hemodialysis Coping Esc Anna Nery. Esc Anna nery. 20 (1), 147-154. Akses Online pada tanggal 2 Maret 2016. URL:
http://www.scielo.br/scielo.php?pid=S1 414-

81452016000100147\&script=sci_artte $x t \& t l n g=e n$.

Riset Kesehatan Dasar (Riskesdas). (2018). Badan Penelitian dan Pengembangan Kesehatan Kementerian RI tahun 2018. Diakses pada mei 2019. URL: http://www.depkes.go.id/resources/dow nload/infoterkini/materi_rakorpop_201 8/Hasil\%20Riskesdas\%202018.pdf .

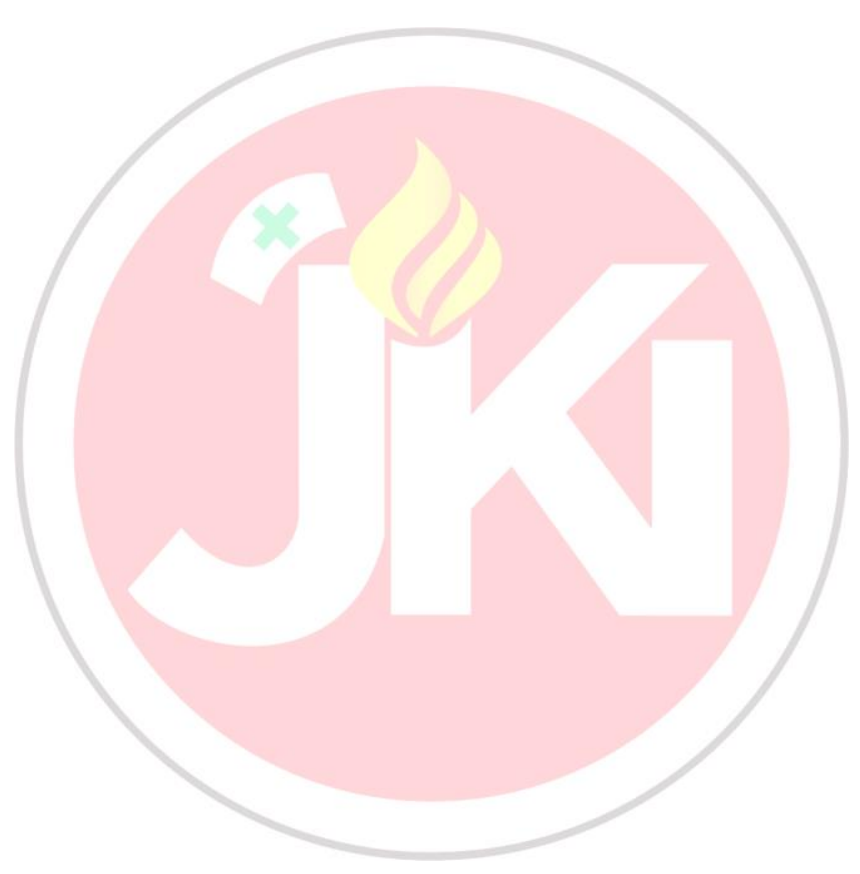

